\title{
CENTRIFUGALLY MANUFACTURED HOLLOW CONCRETE-FILLED STEEL TUBULAR COLUMNS
}

\author{
Artiomas Kuranovas $^{1}$, Audronis Kazimieras Kvedaras ${ }^{2}$ \\ Dept of Steel and Timber Structures, Vilnius Gediminas Technical University, \\ Saulètekio al. 11, LT-10223 Vilnius, Lithuania \\ E-mail: 1 artiomas.kuranovas@stst.vgtu.lt; ${ }^{2}$ akve@st.vgtu.lt \\ Received 30 May 2007; accepted 22 Oct 2007
}

\begin{abstract}
Hollow concrete-filled steel tubular elements (H-CFSTs) represent a type of composite steel-concrete elements. These elements are usually produced by spinning. During this process wet concrete mix in the steel tube is displaced and compacted by centrifugal force and the concrete core so formed achieves better physical and mechanical properties in comparison with other compaction methods. These improvements are related to concrete density, Young's modulus, Poisson's ratio, compressive strength, deformability as well as to a more uniform distribution of fine and coarse aggregates and binding particles along the thickness of the hollow concrete core formed by multi-layering centrifugation process. The peculiarities of the spinning process, recommendations for proportioning the components for the specimens manufacture, spinning time needed for displacement and compaction of concrete mix, preparation of specimens for testing and testing methods used are presented in this paper.
\end{abstract}

Keywords: composite structures, hollow concrete-filled steel tubes, multi-layered core, spinning, centrifugation, manufacture, technology.

\section{Introduction}

Civil engineers in the past realised the potential of combining the ductility and tensile strength of steel with the compressive strength of the cheaper concrete in the construction of structural members, often called composite steel-concrete structures. Such members utilise the advantages of both materials: the high strength and ductility of steel with high compressive strength and stiffness and relative cheapness of concrete. As composite members, solid concrete-filled steel tubular (CFST) elements were described at the beginning of the $20^{\text {th }}$ century [1]. The studies of hollow concrete-filled members (Fig 1a) started in the last 3 decades of the $20^{\text {th }}$ century [2-20].

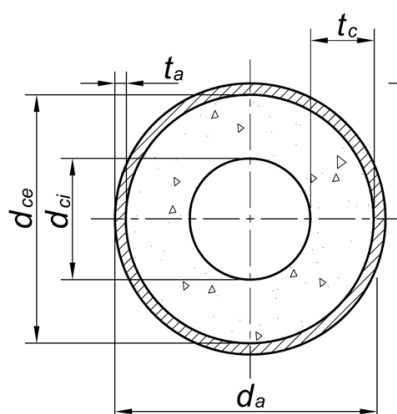

a)

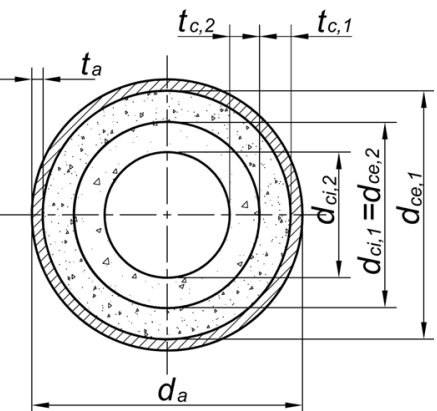

b)
Fig 1. Cross-section of CFTS element with single- (a) and double-layered (b) concrete core
The advantages of these hollow elements in respect to solid CFST ones are: a) smaller concrete consumption and dead permanent load to the building, b) pipes, cables and other installations of the building may be installed inside the columns, c) a higher relative compressive strength, d) an easier and cheaper assembly. Hollow CFST members may also be produced with a concentrically layered concrete core (double-layered, triple-layered or more, see Fig 1b) that increases physical properties, such as density, Young modulus, more homogeneous structure of concrete core particles etc, and mechanical ones, such as load-bearing capacity of the whole member (relative compressive resistance, deformability), Poisson's ratio [21]. The mechanical reasons were discussed in [9]. In the present article other technological aspects are analysed.

\section{Spinning}

The spinning process as a compaction method was started to be widely applied at the beginning of the $20^{\text {th }}$ century in metallurgy and production of concrete and reinforced concrete members, mainly of annular crosssection.

Using science innovations of the first three decades of the $20^{\text {th }}$ century, E. Morkvart [22] formulated the main theoretical propositions of centrifuging. Applying some postulates and laws of mechanics of solid body, he derived relationships, now widely used in producing of centrifuged reinforced concrete members.

The point of centrifuging is that during the spinning formwork (or steel tube as external shell) the plastic wet 
concrete mix is uniformly distributed by the centrifugation pressure, and, as a result, distances between the aggregates and other solid particles diminish and weakly bonded excess water with some other particles is pressed out from the compacted concrete mix. The increase of concrete density helps retain a circular shape.

Physical centrifuging results in a decrease of concrete porosity and an increase in homogeneity and strength. Depending on the concrete mix components, compaction mechanisms and methods can vary. For a lower quantity of excess water the stiffness of the concrete mix is higher, and a more intensive mechanical action on it must be applied. Compaction of stiff mixes requires some action which influences rupture of mix structure and transfers it to a more viscous substance.

The centrifugation consists of 4 phases (Fig 2): $1^{\text {st }}$ phase - uniformly distribution of wet concrete mix along formwork or steel tube length at low rotational velocity of centrifuge machine (Fig 2a); $2^{\text {nd }}$ phase - formation of concrete core layer, as the rotational velocity is increased and centrifugal forces start to act, so compression of wet concrete mix to formwork surface begins (Fig 2b); $3^{\text {rd }}$ phase - compaction of concrete core, with rotational velocity increased to the calculated one, when concrete core achieves a more uniform thickness, squeezing water out of the mix starts; $4^{\text {th }}$ phase - with rotational velocity doubled further compaction of the concrete continues and the core reaches its designed uniform thickness and excess water is pressured out of concrete core.

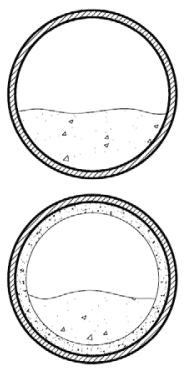

a)
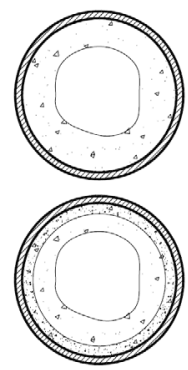

b)
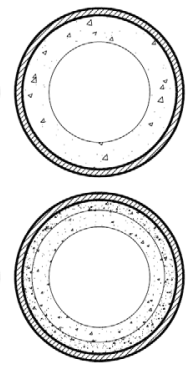

c)
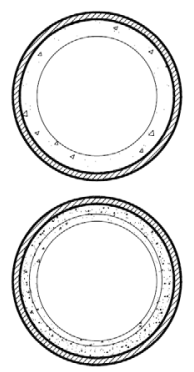

d)
Fig 2. Spinning phases on single and multi-layered H-CFST's: distribution of wet concrete (a), formation of concrete core (b), compaction of concrete (c), water squeezed out under compaction (d)

Physical-mechanical characteristics of centrifuged concrete depends on a number of factors: activity of cement and water demand for it, fine and coarse aggregates, excess pulp, granular composition, and proportions of components, volume of cement paste in concrete mix, water-cement ratios (primary $(W / C)_{\text {prim }}$ and residual $\left.(W / C)_{r e s}\right)$, value of centrifugal pressure $p$, centrifugation mode, concrete mixing process.

All these factors influence the centrifuged concrete characteristics and must be taken into account when calculating the correct concrete proportions by empirical and theoretical methods. The following factors must be taken into account when designing the concrete mix: activity and water demand of the cement, percentage of mineral admixtures and content of dusty particles in it, granular composition of fine and coarse aggregates, porosity and density of coarse and fine aggregates without dusty particles, maximum number of specimen rotation or pressure, mode of centrifugation (single-layered or multilayered).

The wet concrete mix is an elastic-plastic-viscous substance, the laws and postulates of solid bodies are not valid to it, because deformation of this compressed substance under radial pressure changes gradually, while action applied to a solid body immediately causes its deformation.

In wet concrete, cement paste is a compressed substance, and redistribution of pressure in it depends on the resistance under which the pressed out water reaches during motion through obstacles of water filtrating canals in the spinning concrete. Therefore time is needed for concrete compaction under pressure.

Applying the radial pressure to the cement substance, it directly transfers to water between particles of wet concrete mix. As a result, hydrostatic pressure appears and causes water filtration, and compaction of cement paste starts. As a result, density and compression strength of concrete mix increase, and at certain conditions the equilibrium between hydrostatic pressure and concrete resistance appears. This resistance characterises the end of filtration. Since this moment the spinning pressure is fully applied to solid particles of concrete mix. Between these particles only a thin water film exists.

\subsection{Distribution of wet concrete in spinning process}

The first phase of spinning is the distribution of the concrete mix along the steel tube (Fig 2a).

The residual water-cement ratio of wet concrete $(W / C)_{\text {res }}$ does not characterise the optimal spinning conditions, because concrete compression strength and density depend on the distribution of the concrete mix in the steel tube.

Wet concrete mix is placed into the form during the spinning. Under the action of radial pressure during spinning concrete starts to distribute itself away from the ends of the form, and it will run until the equilibrium between the internal wet concrete mix compression resistance and the force stimulating distribution of it takes place.

Before manufacturing the load-bearing members it is important to calculate the optimum number of steel tube rotations and value of radial pressure needed for uniform distribution of concrete mix along the steel tube and to ensure its sufficient bonding with internal surface of steel tube during next phases of centrifuging (Fig 2a,b). For choosing the spinning parameters it is also important to calculate the absolute value of spinning pressure (optimal number of rotations), when maximum value of radial pressure on concrete mix (Fig 2c, d).

The spinning pressure necessary for a uniform distribution can be calculated from Eq [12]:

$$
p \approx 90 \cdot 10^{-10} \cdot \frac{r_{c e}^{3}-r_{c i}^{3}}{r_{c e}} \cdot n^{2},
$$


where: $r_{c e}$ and $r_{c i}$ are external and internal radiuses of single-layered concrete core (Fig $32 \mathrm{a}$ ). In case of multilayered concrete core, the symbols would be: $r_{c e, j}, r_{c i, j}-$ of outer, $r_{c e, j+1}, r_{c i, j+1}$ - of inner concrete layers, where $j=1,2, . ., n-1-$ number of layers (Fig $32 \mathrm{~b}$ ).

According to [22], the value of radial pressure is 3,5-3,7 times greater than the weight of the load-bearing member, concrete plus steel tube. Thus the needed number of steel tube rotations for uniform distribution of concrete mix can be as:

$$
n_{d i s t}=700 \sqrt{\frac{r_{c e}^{2}-r_{c i}^{2}}{r_{c e}^{3}-r_{c i}^{3}}} .
$$

Boundary condition of equilibrium forces, so that the concrete mix during spinning will not lose bonding between it and steel tube surface can be written as: $p=q$

(where $q$-weight of concrete mix to steel tube surface area). Finally, the number of rotations needed to achieve bonding at interface between wet concrete and steel tube is calculated by the equation

$$
n_{\text {spin }}=370 \sqrt{\frac{r_{c e}^{2}-r_{c i}^{2}}{r_{c e 2}^{3}-r_{c i}^{3}}} .
$$

Combining Eqs (2) and (3) shows that:

$$
n_{\text {dist }}=1.9 n_{\text {spin }} \text {. }
$$

Hence the number of steel tube rotations needed for uniform distribution of concrete core along tube $n_{\text {dist }}$ is nearly twice the number $n_{\text {spin }}$ needed to ensure the bonding at interface between H-CFST components.

\subsection{Compaction of wet concrete by spinning}

After the distribution of concrete mix the first phase of the spinning process, the rotational velocity of steel tube is uniformly increased until the calculated value needed for concrete compaction is reached. The capability of concrete mix to distribute itself uniformly on the internal surface of steel tube is conditioned by its ability to retain plastic features of substance under the sway of radial pressure of corresponding value, at which the rupture does not appear in radial compressed concrete in rotating tube.

The number of steel tube rotations $n$ depends on construction of centrifugal machine, power of machine engine, diameter of steel tube.

The term "layer" will be used for separate parts of multi-layer concrete core which were centrifuged at different time. The term "sub-layer" will be used for structural analysis of a layer which is divided into smaller parts for analysis of the processes taking place when centrifuging.

The radial pressure is non-uniformly distributed through the concrete sub-layer thickness, it changes from a minimum value on the internal surface to a maximum on the external one (Fig 3). Thus with the increase of radial pressure above the limit value of external sub-layer compression has been achieved. Then compaction of sublayers distributed closer to the steel tube starts. Therefore, as the radial pressure is increased due to further spinning of steel tube under an increased rotational velocity, a more uniform distribution of solid particles of concrete core is achieved, and the process of compaction starts.

The density, $W / C$ ratio and porosity of wet concrete is not constant through the thickness of the concrete layer during spinning.

The analysis of Eq 1 shows that maximum radial pressure acts on the external surface of the forming layer at $r_{c e}$ (in single-layered case Fig $32 \mathrm{a}$ ), and at $r_{c e, 1}, r_{c e, 2}$ (in case of double-layered core Fig 3 2b). Approaching the internal surface of the concrete core, whether at $r_{c i}$, or at $r_{c i, 1}, r_{c i, 2}$, the values of radial pressure decrease. Thus, in conclusion, the variation of radial pressure across the thickness of concrete core is similar to hydrostatic pressure, ie by the triangular law.

Because of such a radial pressure distribution, water cannot be pressed out uniformly from the whole concrete core volume through the thickness. During spinning the water will be more pressed out from the external more radially compressed sub-layers. Approaching the internal surface of concrete core, less water will be pressed out. From an internal sub-layer of concrete core, where the radial pressure is close to zero (Fig $3 \mathrm{lb}, 2 \mathrm{~b}$ ), water will be not pressed out at all. But the water from intermediate and external sub-layers is pressed out through the above-mentioned internal sub-layer. It happens because of continuous hydrodynamic process of water filtration from one concrete sub-layer to other until all excess water will be pressed out from the spinning member when the equilibrium between external and internal forces is reached. Because of the triangular distribution of radial pressure through the thickness of formed concrete core there will be different amounts of water in different sublayers and layers.

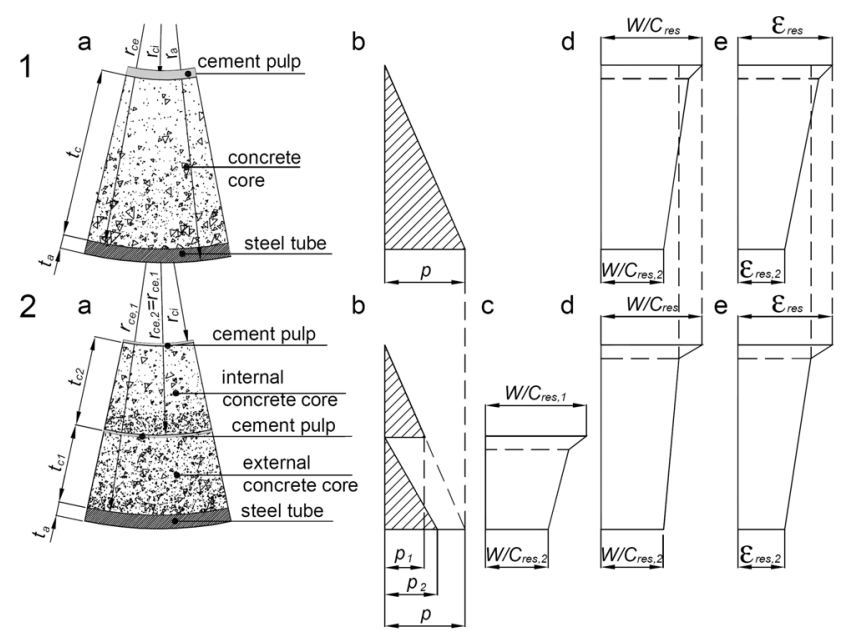

Fig 3. Part of cross-section of single-layered 1a) and double-layered 2a) concrete-filled steel tubes. Diagrams of: b) radial pressure $p, \mathrm{c}$ and d) residual water-cement ratio $(W / C)_{\text {res }}$ for each layer and e) residual porosity coefficient $\varepsilon_{\text {res }}$ 
With the increase of the steel tube rotational velocity excess water starts to be pressed out from the wet concrete which is compacted until the moment when it achieves the properties of a pseudo-solid body. Decreasing the quantity of excess water in concrete results in a higher compression resistance.

Changing the value of $\mathrm{W} / \mathrm{C}$ ratio through the centrifuged concrete core may be represented by the graphicalanalytical method, dividing the concrete core into $s$ sublayers [22] and calculating the values of radial pressure for each sub-layer. The resultant radial pressure diagram is represented by a straight-line triangle with the maximum extreme value $p$ at the external surface of the core (Fig 3 ).

The character of concrete core porosity distribution through sub-layers $\varepsilon_{\text {res }}$ shows an anisotropic density of spun concrete. Non-linear distribution of diagrams can be explained by the existence of directed microscopic water filtrating channels through the thickness of concrete core. The number and dimensions of such channels are increasing in direction as we move from external to internal core surfaces. These micro-channels (Fig 4) do not disappear after water filtration because of a high structural hardness of the wet concrete after spinning. From the external to the internal surface radially directed micro-channels openings consolidate to macro-channels at the middle part of concrete core thickness (Fig 4 a), and they join into uniformly distributed filtrations channels through the core thickness filtration channels and disappear when approaching the internal core surface. This phenomenon can be explained by liquefaction of wet concrete in the internal sub-layers by water pressed out from external sub-layers. Because of this porosity the external sub-layer is of relatively higher strength than the internal one.

For the above-mentioned reasons the conclusion may be made that by being multi-layered the possibility exists for a considerable diminish of the filtration channel quantity and width, for closing their outlets with cement substance and for eliminating their propagation to other layers.

Using the graphical-analytical method these propositions can be improved. In Fig 3 the concrete core layer is divided into concentric sub-layers and diagrams of pressure $p,(W / C)_{r e s}$ and $\varepsilon_{\text {res }}$ are shown taking into account that excess water after centrifugation has been squeezed out of the concrete. The radial pressure for each concrete sub-layer is determined independently of other sub-layers. Graphical distribution of this pressure in each sub-layer is presented by triangular diagrams. During the spinning of the first layer the $(W / C)_{\text {res }}$ distribution through it thickness is the same as in Fig $3 \mathrm{c}$. It shows that the layer thickness does not influence $(W / C)_{\text {res }}$ value.

If the excess of pressed out water is eliminated after the first layer compaction, during centrifuging the second layer excess water will be pressed out mostly from it. Additional compaction of the first layer will proceed by an increased pressure from the mass of both layers because of deformation of water filtration channels and partly pressed out residual excess water from the first layer.
However, most water has been eliminated from the first layer just before placing concrete mix for the second layer in the tube. This causes a less development of filtrating channels in both layers in respect of development of channels during centrifugation of the concrete mix for both layers at once (Fig 4 b).

In the same manner compaction of further layers may proceed. Consequently, during centrifugation of the concrete mix layer by layer, difference of $(W / C)_{\text {res }}$ values in each layer will be less than during centrifugation of all the concrete mix at once (Fig 3), though the value of radial pressure after compaction layer by layer is the same as for single layer compaction.

Non-linear distribution of $\varepsilon_{\text {res }}$ in the compacted layer by layer concrete core shows a significant decrease of wet concrete density anisotropy, absence of filtration channels and a more uniform distribution of pores.

Analysis of $\varepsilon_{\text {res }}$ (Fig $3 \mathrm{~d}$ ) shows that during the concrete compaction layer by layer a less porous structure of concrete is obtained compared with compaction by single-layering. Experiments [22] show (Table 1) an average porosity of concrete compacted layer by layer being of 10-12\% less than the porosity for single-layer spinning. With a decreasing porosity the form of channels also changes.

Table 1. Porosity of concrete for centrifuged core of CFST

\begin{tabular}{|c|c|c|}
\hline \multirow[b]{2}{*}{ Specimen } & \multicolumn{2}{|c|}{ Porosity (\%) } \\
\hline & Layer & Average \\
\hline Single-layered & - & 14,6 \\
\hline $\begin{array}{l}\text { Double-layered } \\
\text { 1st layer.......................... } \\
\text { 2nd layer....................... }\end{array}$ & $\begin{array}{l}12,8 \\
15,1 \\
\end{array}$ & 14,0 \\
\hline 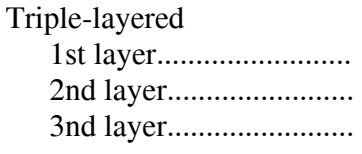 & $\begin{array}{l}10,0 \\
10,8 \\
14,2\end{array}$ & 11,6 \\
\hline 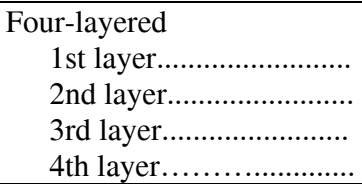 & $\begin{array}{c}9,2 \\
10,6 \\
12,6 \\
14,3\end{array}$ & 11,6 \\
\hline
\end{tabular}

The water from wet concrete is pressed out together with fine fractions of cement during centrifuging. These fine particles plug filtrating channels close to the layer surfaces and produce a zone without filtration channels. A cross-section of layered concrete core shows each layer consisting of 3 parts: 1) internal - concrete without micro-channels, 2) middle - with micro- and macrochannels, 3) external - cement paste with closed channels (pulp). According to experimental results [22], the actual homogenous structure of the concrete core can be achieved after the $3^{\text {rd }}$ layer centrifugation, whereas after the $4^{\text {th }}$ layer compaction, the porosity of the concrete core does not change significantly. In the opinion of the authors of this paper, the number of layers for achieving the most homogeneous structure of the concrete core directly depends on concrete core thickness of and on the con- 
crete mix contents (size, binding properties etc). The anisotropy of concrete density depends not only on the homogeneity of the cement paste, but also on the character of aggregate distribution through each concrete layer, because centrifugal forces are directly proportional to the mass of the centrifuged element.

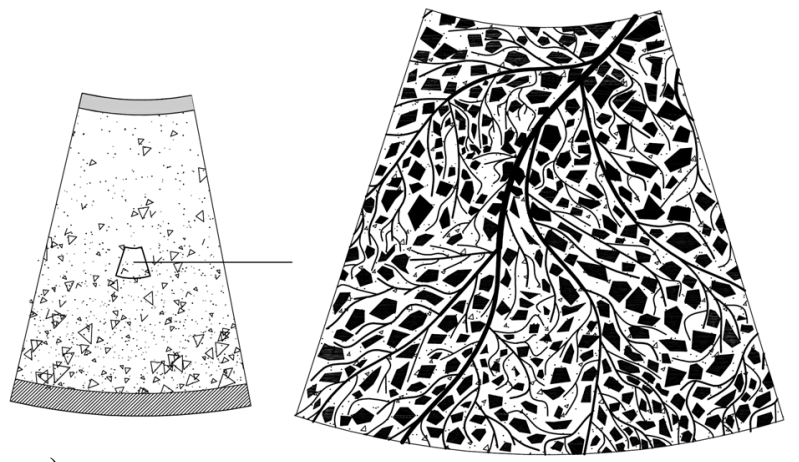

a)

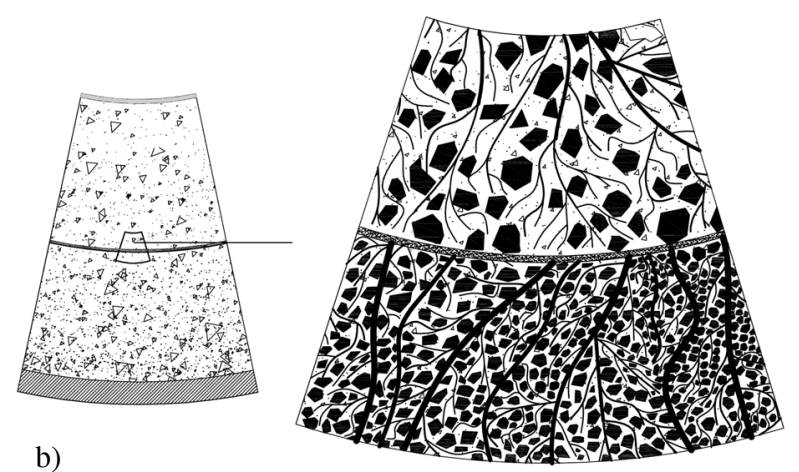

Fig 4. Distribution of micro- and macro-channels in concrete core for single- a) and double-layered; b) elements

Investigations show [22] that if concrete after spinning is rotated once more without additional water to the mix again, a corresponding quantity of water will be pressed out. It confirms that after spinning of concrete the residual water-cement ratio $(W / C)_{\text {res }}$ is not equally distributed through the concrete layer. If the wet concrete mix is spun again, water uniformly redistributes and after a repeated spinning, the corresponding water quantity is pressed out from newly formed concrete layers. If wet concrete after the first spinning has a value greater than $(W / C)_{\text {res }}$, then a greater water quantity will be pressed out during further spinning.

During centrifugation the heaviest and coarse particles are pressed to the external surface of layers and the fines are mainly distributed close to the internal surface because of their lighter weight. Therefore the structure of centrifuged concrete differs, as the aggregate particles are distributed non-uniformly. This non-homogeneous distribution of particles decreases the whole strength of $\mathrm{H}$ CFST member. But this disadvantage can be eliminated by multi-layered centrifugation process.

The centrifugation time needed to press out excess water from a concrete mix according to [22] can be determined by the following equations for cement paste and concrete respectively:

$$
\begin{gathered}
t_{\text {cent }, \text { cem }}=0,825 \frac{t_{c}}{p}, \\
t_{\text {cent }, c}=0,755 \frac{t_{c}}{p},
\end{gathered}
$$

where $t_{c}$ - thickness of concrete layer, $p$ - radial pressure.

Analysis of the Eqs 5, 6 suggests the conclusion that compaction of cement paste requires more time than for concrete. Consequently, the composition of the concrete mix aggregates plays a more significant role when manufacturing spinning elements. This also applies to the cement because with a water demand increase the the water/ cement ratio also increases. To reduce manufacturing time and to improve quality of the spun elements the velocity of element rotation must be increased, and consequently the radial pressure.

The concrete mix must have a required viscosity to ensure a uniform thickness of layers during their formation and compaction. Thus, a certain slump of concrete must be achieved. In [22] recommendations and regulations on how to get the required stiffness of the mix are provided. Cone slump of concrete mix is determined:

$$
s=33,2 \frac{V_{f a}}{V_{f a}+V_{c a}} V_{c p},
$$

where: $V_{f a}, V_{c a}, V_{c p}$ - volumes of fine, coarse aggregates and cement paste respectively.

\subsection{Centrifugal machine}

A H-CFST can be produced using spinning machine where tube rotation proceeds by belts or by axial spinning of rolls.

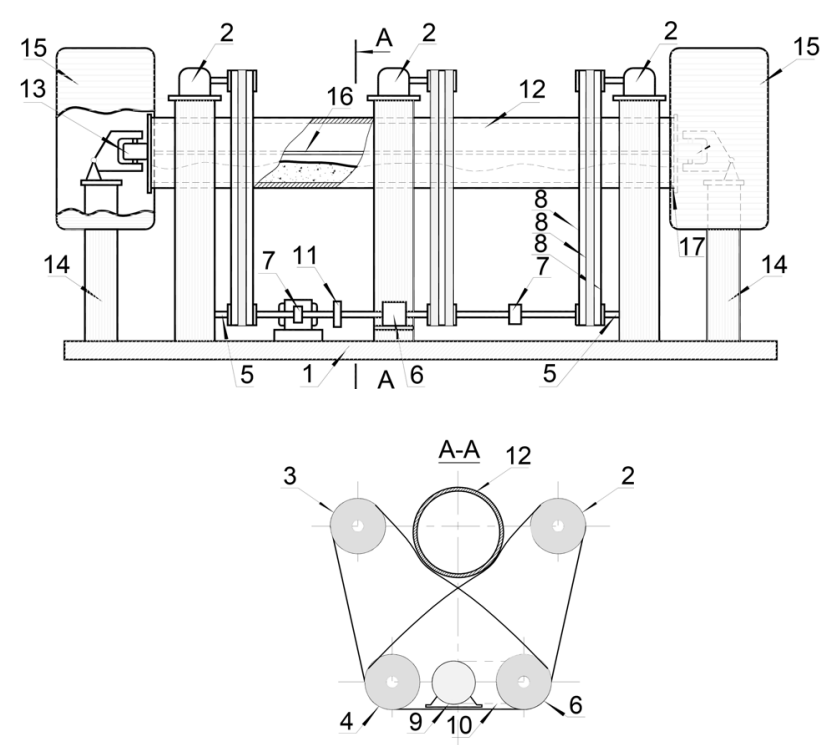

Fig 5. Scheme of strap-spinning machine

The spinning machine with belts (Fig 5) (specimens produced by this type of machine) consists of a frame (position 1) to which upper (positions 2, 3) and lower supports (position 4), guide and running axles (positions $4,5)$ are fixed. The guide axle is connected to running axels by sleeve (position 7). The supports are fixed sym- 
metrically to the spinning axis and connected with belts (Fig 4). The rotation forces are transferred from an electrical engine to the running axle (position 9) by belts (position 10) and support (position 11), which is installed on the running axle. A steel tube (position 12) is located, before spinning is located on these belts. To prevent the longitudinal movement special supporting hinges are arranged (position 13), fixed to brackets arranged in the end supports.

To avoid splashing of mix components from the tube, special manufactured end-plates with seals rubber (position 16) were installed at the ends of tube and pressed to the tube ends by a threaded steel rod (position 17) with screws and washers.

The spinning machine KOHT-1 has 4 spinning velocities. Linear velocity of the straps for the $1^{\text {st }}$ spinning step $-300 \mathrm{~m} / \mathrm{min}$, for the $2^{\text {nd }}-455 \mathrm{~m} / \mathrm{min}$, for the $3^{\text {rd }}-$ $595 \mathrm{~m} / \mathrm{min}$, for the $4^{\text {th }}-910 \mathrm{~m} / \mathrm{min}$. Linear velocities were measured using tachometer T10.

\section{Manufacturing and testing H-CFST}

\subsection{Materials}

The steel circular hollow sections (CHS) Ø219x $5 \mathrm{~mm}$ were used for manufacturing the specimens. Yield and ultimate strength of CHS steel were determined by testing the standard steel plate coupons and non-standard rings (Figs 7-9). The coupons and rings were cut off from steel tube. According to the results of these tests, the S355 steel grade was determined.

The concrete mix for single- and double-layered specimens was designed for compressive cube strength at 28 days of approx $30 \mathrm{MPa}$ (Table 2). The mix proportions used are presented in Table 3.

For fine aggregate the quartz sand of $0,2 \mathrm{~mm}$ main grain size and Portland cement of CEMII/A-L $42.5 \mathrm{~N}$ grade as binder material were used. The elastic modulus of steel and concrete used for experimental specimens were $212 \mathrm{GPa}$ and 34,6 GPa respectively.
The concrete mix components were calculated by computer software CONCRETE (Fig 6) using calculated cone slump and determined granulation characteristics of aggregates.

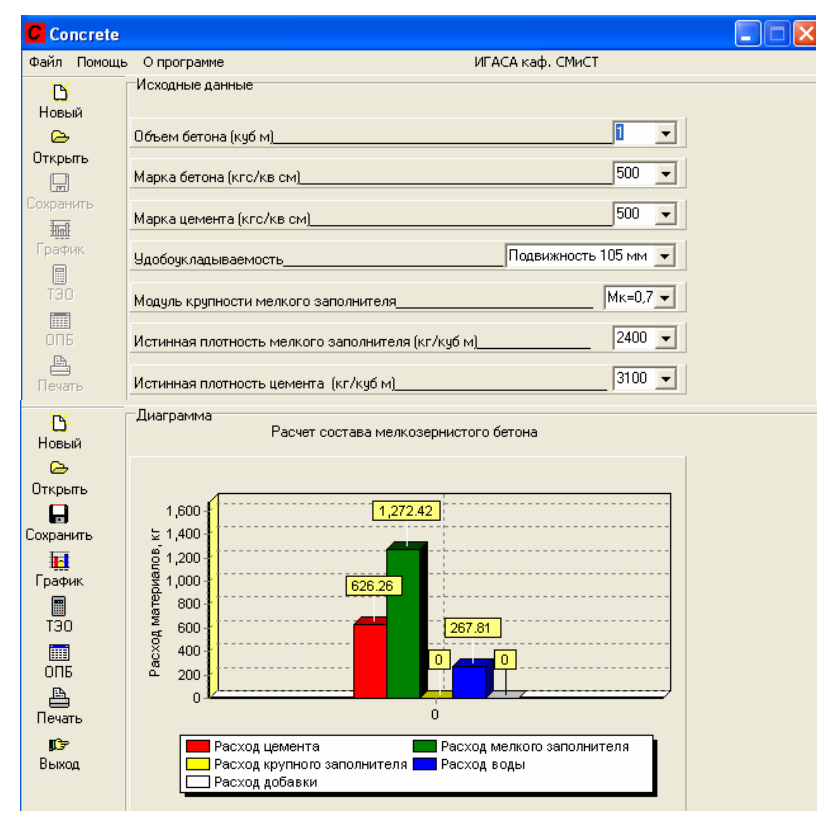

Fig 6. Proportioning concrete mix components using computer software CONCRETE

\subsection{Manufacturing}

All physical and mechanical parameters of materials and specimens are presented in Tables 2, 3. The initial water/cement ratio and slump of concrete cone were taken according to the recommendations [22]. But because of the use of very fine aggregates a required slump of $100 \mathrm{~mm}$ was necessary (Eq 7) for centrifugation but with such proportions of concrete it was not achieved and additional water had to be used (Table 3, number in brackets).

Table 2. Geometrical, weight parameters, ultimate loads, stresses and grades of concrete cubes

\begin{tabular}{|c|c|c|c|c|c|c|c|c|c|c|c|c|}
\hline \multirow{2}{*}{$\begin{array}{c}\text { Type of } \\
\text { specimen }\end{array}$} & \multirow{2}{*}{ 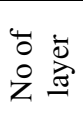 } & \multicolumn{11}{|c|}{ Parameters of concrete cubes } \\
\hline & & Nr. & $\begin{array}{c}a \\
(\mathrm{~mm})\end{array}$ & $\begin{array}{c}b \\
(\mathrm{~mm})\end{array}$ & $\begin{array}{c}h \\
(\mathrm{~mm})\end{array}$ & $\begin{array}{l}\text { Weight } \\
(\mathrm{kg})\end{array}$ & $\begin{array}{c}A \\
\left(\mathrm{~cm}^{2}\right)\end{array}$ & $\begin{array}{c}V \\
\left(\mathrm{~cm}^{3}\right)\end{array}$ & $\begin{array}{c}\rho, \\
\mathrm{kg} / \mathrm{m}^{3}\end{array}$ & $F, \mathrm{kN}$ & $\begin{array}{c}f_{c} \\
\mathrm{MPa}\end{array}$ & Grade \\
\hline \multirow{5}{*}{$\begin{array}{l}\text { Single- } \\
\text { layered }\end{array}$} & \multirow{5}{*}{ I } & 1 & 99,7 & 101,7 & 99,8 & 2,071 & 101,4 & 21,0 & 2047 & 332,5 & 32,79 & 29,84 \\
\hline & & 2 & 100,0 & 100,8 & 99,7 & 2,079 & 100,8 & 20,9 & 2069 & 360,8 & 35,79 & 32,57 \\
\hline & & 3 & 99,4 & 101,9 & 99,8 & 2,101 & 101,3 & 21,4 & 2078 & 354,0 & 34,95 & 31,80 \\
\hline & & 4 & 99,6 & 101,9 & 98,9 & 2,079 & 101,5 & 21,0 & 2071 & 362,1 & 35,68 & 32,47 \\
\hline & & Ave(4) & 99,7 & 101,6 & 99,6 & 2,083 & 101,2 & 21,1 & 2066 & 352,4 & 34,80 & 31,67 \\
\hline \multirow{10}{*}{$\begin{array}{l}\text { Double- } \\
\text { layered }\end{array}$} & \multirow{5}{*}{$\frac{\overline{\vec{\sigma}}}{\frac{\dot{\sigma}}{\tilde{m}}}$} & 1 & 91,0 & 100,5 & 102,0 & 1,996 & 91,5 & 20,5 & 2140 & 375,0 & 41,00 & 37,31 \\
\hline & & 2 & 95,0 & 100,2 & 100,5 & 2,033 & 95,2 & 20,5 & 2125 & 349,0 & 36,66 & 33,36 \\
\hline & & 3 & 93,5 & 101,0 & 102,0 & 2,033 & 94,4 & 20,9 & 2111 & 377,0 & 39,92 & 36,33 \\
\hline & & 4 & 98,7 & 101,6 & 102,9 & 2,064 & 100,3 & 21,6 & 2000 & 337,5 & 33,66 & 30,63 \\
\hline & & Ave(4) & 94,6 & 100,8 & 101,9 & 2,032 & $\mathbf{9 5 , 3}$ & 20,9 & 2094 & 359,6 & 37,81 & 34,41 \\
\hline & \multirow{5}{*}{ 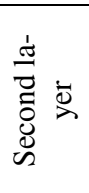 } & 1 & 99,5 & 95,0 & 102,0 & 2,030 & 94,5 & 19,7 & 2105 & 324,1 & 34,29 & 31,20 \\
\hline & & 2 & 99,5 & 98,0 & 101,5 & 2,076 & 97,5 & 20,6 & 2098 & 311,5 & 31,95 & 29,07 \\
\hline & & 3 & 100,0 & 97,0 & 101,0 & 2,059 & 97,0 & 20,2 & 2102 & 312,9 & 32,26 & 29,35 \\
\hline & & 4 & 99,7 & 99,1 & 102,0 & 2,079 & 98,8 & 21,0 & 2063 & 331,2 & 33,52 & 30,50 \\
\hline & & Ave(4) & 98,1 & 97,3 & 101,6 & 2,061 & 97,0 & 20,4 & 2092 & 319,9 & 33,00 & $\mathbf{3 0 , 0 3}$ \\
\hline
\end{tabular}


Table 3. Quantities of materials used for manufacturing CT and CFST specimens

\begin{tabular}{|c|c|c|c|c|c|c|c|c|c|}
\hline \multirow[b]{2}{*}{ No } & \multirow{2}{*}{$\begin{array}{l}\text { Length of } \\
\text { specimen, } \\
\text { mm }\end{array}$} & \multirow{2}{*}{$\begin{array}{l}\text { No of } \\
\text { speci- } \\
\text { mens }\end{array}$} & \multirow{2}{*}{$\begin{array}{l}\text { Initial } \\
\text { length of } \\
\text { spun } \\
\text { member, } \\
\text { mm }\end{array}$} & \multicolumn{3}{|c|}{ Quantities of materials } & \multirow{2}{*}{$\begin{array}{c}\text { Cement: } \\
\text { aggregate } \\
\text { and W/C } \\
\text { ratio }\end{array}$} & \multirow{2}{*}{$\begin{array}{l}\text { Slump of } \\
\text { concrete } \\
\text { mix, cm }\end{array}$} & \multirow{2}{*}{$\begin{array}{l}\text { Quantity of } \\
\text { water pres- } \\
\text { sured out of } \\
\text { mix, kg }\end{array}$} \\
\hline & & & & $\begin{array}{l}\text { Cement, } \\
\mathrm{kg}\end{array}$ & $\begin{array}{c}\text { Fine } \\
\text { aggregate, } \\
\mathrm{kg}\end{array}$ & $\begin{array}{l}\text { Water, } \\
\mathrm{kg}\end{array}$ & & & \\
\hline 1CFST & 437 & 12 & 5540 & 74,1 & 150,5 & $40,2(8.5)$ & \multirow{10}{*}{$\begin{array}{l}1: 2,03 \\
0,543\end{array}$} & 10,0 & 8,3 \\
\hline \multirow{2}{*}{ 2CFST } & \multirow{2}{*}{437} & \multirow{2}{*}{12} & \multirow{2}{*}{5540} & 42,4 & 86,1 & $23,0(4,9)$ & & 10,5 & 6,2 \\
\hline & & & & 37,1 & 75,5 & $20,1(4,2)$ & & 10,5 & 5,3 \\
\hline \multicolumn{4}{|c|}{$\begin{array}{l}\text { Total quantity of materials for spun } \\
\text { specimens }\end{array}$} & 153,6 & 312,1 & 83,3 & & & \\
\hline $1 \mathrm{C} 219$ & \multirow{3}{*}{$\begin{array}{l}100 \times 100 \\
\times 100\end{array}$} & 4 & \multirow{6}{*}{-} & 1,9 & 3,8 & 1,03 & & 10,0 & - \\
\hline \multirow{2}{*}{$2 \mathrm{C} 219$} & & 4 & & 1,9 & 3,8 & 1,03 & & 10,5 & - \\
\hline & & 4 & & 1,9 & 3,8 & 1,03 & & 10,5 & - \\
\hline 1P219 & \multirow{3}{*}{$\begin{array}{l}400 \times 100 \\
\times 100\end{array}$} & 3 & & 7,6 & 15,2 & 4,12 & & 10,0 & - \\
\hline \multirow{2}{*}{$2 \mathrm{P} 219$} & & 3 & & 7,6 & 15,2 & 4,12 & & 10,5 & - \\
\hline & & 3 & & 7,6 & 15,2 & 4,12 & & 10,5 & - \\
\hline \multicolumn{4}{|c|}{$\begin{array}{l}\text { Total quantities of materials for concrete } \\
\text { prisms and cubes }\end{array}$} & 11,4 & 22,8 & 4,8 & - & & \\
\hline \multicolumn{4}{|c|}{$\begin{array}{l}\text { Quantities of materials for cubes, prisms } \\
\text { and spun specimens }\end{array}$} & 340,8 & 692,1 & 145,6 & - & & \\
\hline \multicolumn{4}{|c|}{$\begin{array}{l}\text { Used quantities of materials for cubes, } \\
\text { prisms and spun specimens with compac- } \\
\text { tion coefficient of } 20 \%\end{array}$} & 409,0 & 830,5 & 174,7 & - & & \\
\hline
\end{tabular}

Centrifugation of the specimens was performed by spinning machine KOHT-1 with the above-mentioned 4 velocities values: $1^{\text {st }}-436 \mathrm{rev} / \mathrm{min} ; 2^{\text {nd }}-611 \mathrm{rev} / \mathrm{min}$, $3^{\text {rd }}-865 \mathrm{rev} / \mathrm{min}, 4^{\text {th }}-1323 \mathrm{rev} / \mathrm{min}$. The required spinning time (Table 4) was determined by recommendations [22] (Eqs 5, 6) and experience of authors and other VGTU scientists.

Table 4. Spinning time of the concrete mix for H-CFST specimens

\begin{tabular}{|c|c|c|c|c|}
\hline \multirow{2}{*}{$\begin{array}{l}\text { Type of } \\
\text { specimen }\end{array}$} & \multirow{2}{*}{$\begin{array}{l}\text { Number of } \\
\text { layers }\end{array}$} & \multicolumn{3}{|c|}{$\begin{array}{l}\text { Number of velocity and spinning } \\
\text { time }\end{array}$} \\
\hline & & No & $t, s$ & $\Sigma t, s$ \\
\hline \multirow{4}{*}{$\begin{array}{l}\text { Single- } \\
\text { layered } \\
\text { 1CFST }\end{array}$} & \multirow{4}{*}{ - } & 1 & 262 & 262 \\
\hline & & 2 & 117 & 379 \\
\hline & & 3 & 561 & 940 \\
\hline & & 4 & 215 & 1155 \\
\hline \multirow{8}{*}{$\begin{array}{l}\text { Double- } \\
\text { layered } \\
2 \mathrm{CFST}\end{array}$} & \multirow{4}{*}{ First layer } & 1 & 115 & 115 \\
\hline & & 2 & 41 & 156 \\
\hline & & 3 & 243 & 399 \\
\hline & & 4 & 88 & 487 \\
\hline & \multirow{4}{*}{ Second layer } & 1 & 134 & 134 \\
\hline & & 2 & 60 & 194 \\
\hline & & 3 & 289 & 483 \\
\hline & & 4 & 110 & 593 \\
\hline
\end{tabular}

After each layer centrifugation residual water was removed from the specimens. Pressured out water quantity is presented in Table 3. Analysis of this data shows that during multi-layered spinning more residual that during multi-layered spinning more residual water $(\sim 30 \%)$ is pressed out with respect to the single-layered process. Consequently, this is proved [22] by the theory and experiments.

After centrifuging the residual water quantity was measured; it was observed that during double-layered centrifuging a greater quantity of residual water was pressed out from the concrete mix than during the singlelayer centrifuging. For determining the initial concrete mechanical properties the cubes and prisms were manufactured from the same concrete mix, compacting them by vibrating.

Single- and double-layered centrifuged H-CFST were cured in the laboratory with an environmental humidity of $21 \%$ and temperature $+16,1{ }^{\circ} \mathrm{C}$.

The concrete cores in the centrifuged specimens were isolated from environmental action by polyethylene film being put at the ends of tubular specimens. The environmental humidity in the internal cavity of the specimens was $82 \%$.

Spinning time of the concrete mix is in Table 4.

\subsection{Preparation of specimens and their testing}

The H-CFST members after 28 days of curing were cut to smaller specimens of $\sim 438 \mathrm{~mm}$ in length. For determining mechanical properties of single- and doublelayered centrifuged concrete cores the steel shells were cut and taken off from some specimens, and H-CT elements were received. The stub steel tubes ST, H-CT and H-CFST elements of $438 \mathrm{~mm}\left(2 D_{a}\right)$ height were tested under an axial compression. Concrete cubes and prisms were tested after 28 days curing in natural humidity camera.

All longitudinal $\varepsilon_{L}$ and transversal $\varepsilon_{T}$ strains were measured by ALMEMO hardware at the middle height of specimens using the vertical and horizontal glued strain-gauges (Figs 7-10), and load-bearing capacity was fixed as the squash load on the testing machine scale. To obtain strains from internal concrete core glued strain gauges steel plates with vertical and horizontal channels for electrical cables were produced (Fig 11). 


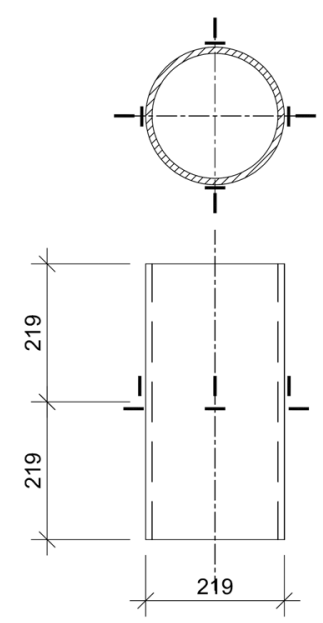

a)

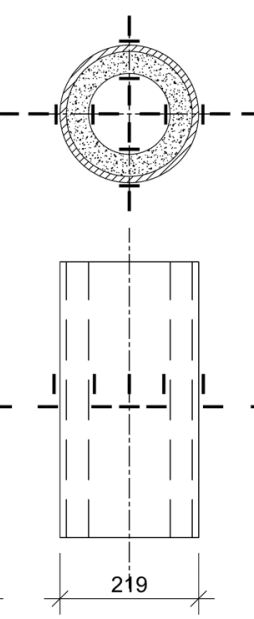

b)

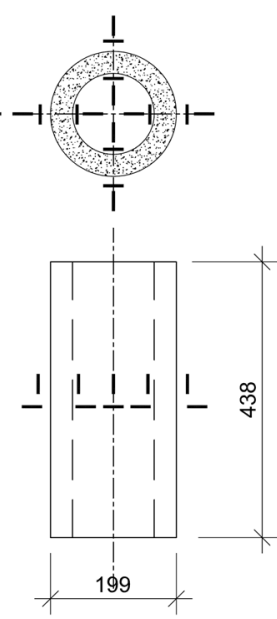

c)
Fig 7. Distribution of strain gauges in ST a), H-CFST b), H-CT c)

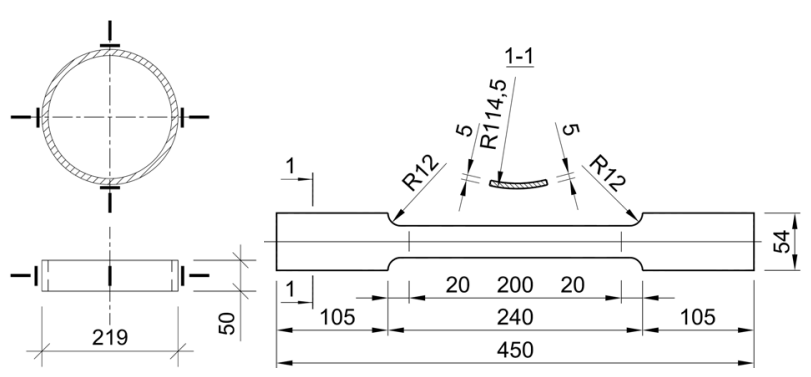

Fig 8. Distribution of a) strain gauges and geometry of RST, of b) coupon for steel properties determination

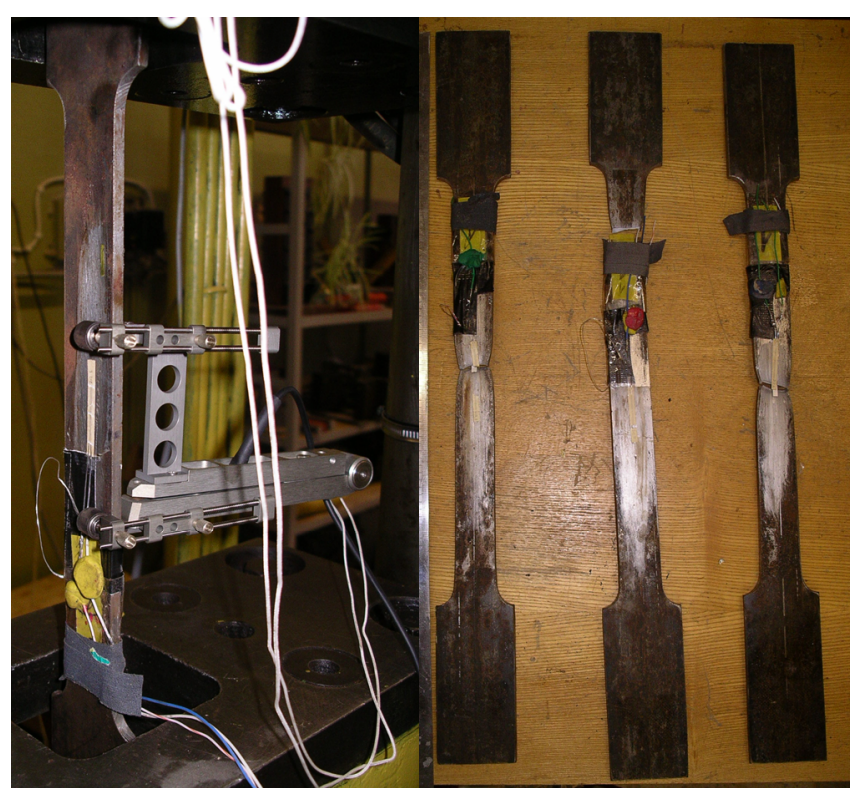

a)

b)

Fig 9. Testing a) steel coupon, b) tested steel coupons

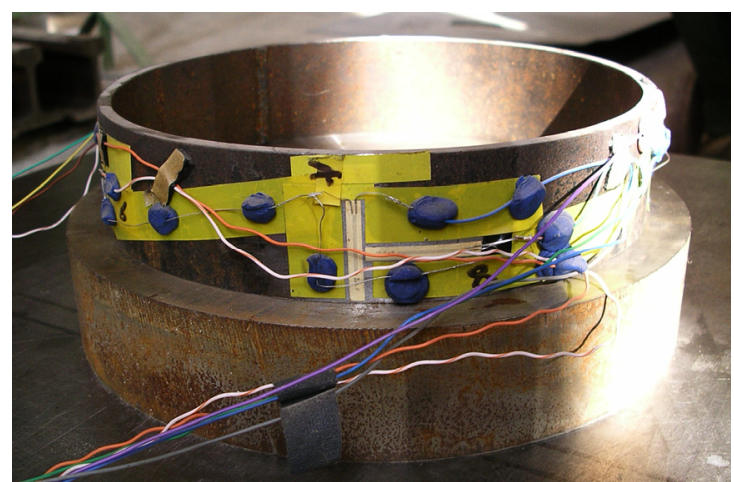

Fig 10. Steel ring SR specimen

All ST and H-CFST specimens have buckled by „elephant foot" mode near the lower support plate of the testing machine (Figs 12, 13). Concrete core in H-CFST specimen failed near the loading machine plate, but H-CT specimen failed due to cracking along the all length of the specimen (Fig 14). In the single-layered elements failure of the concrete core went deeper through the core thickness than in the double-layered because of an additional interaction between layers.

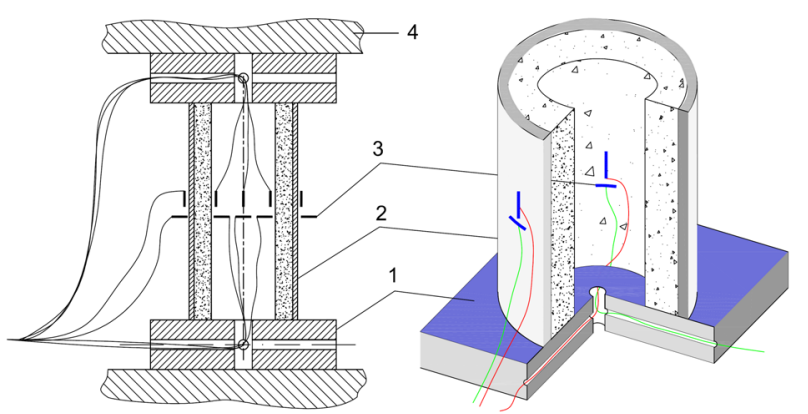

Fig 11. Testing the H-CFST specimen: 1 - steel plate with holes for strain gauge wires, 2 - H-CFST specimen, 3 strain gauges, 4 - steel plate of the test machine

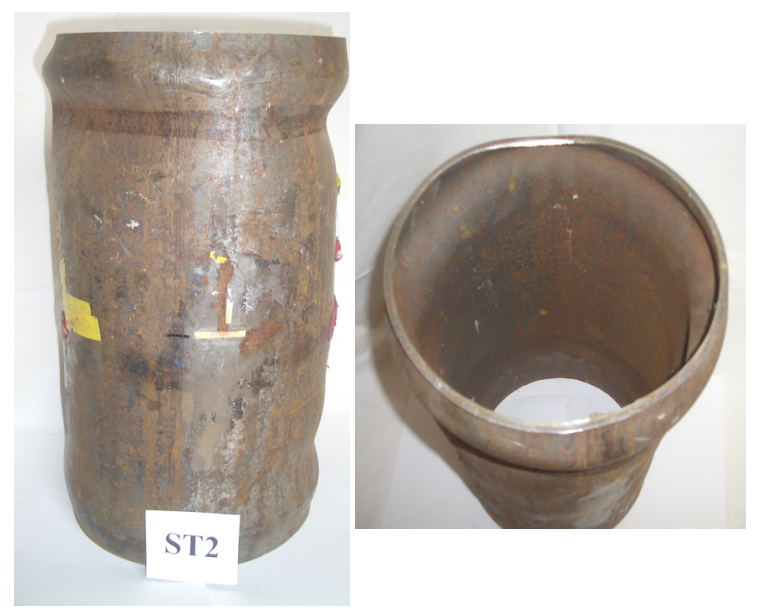

Fig 12. ST tested specimen 


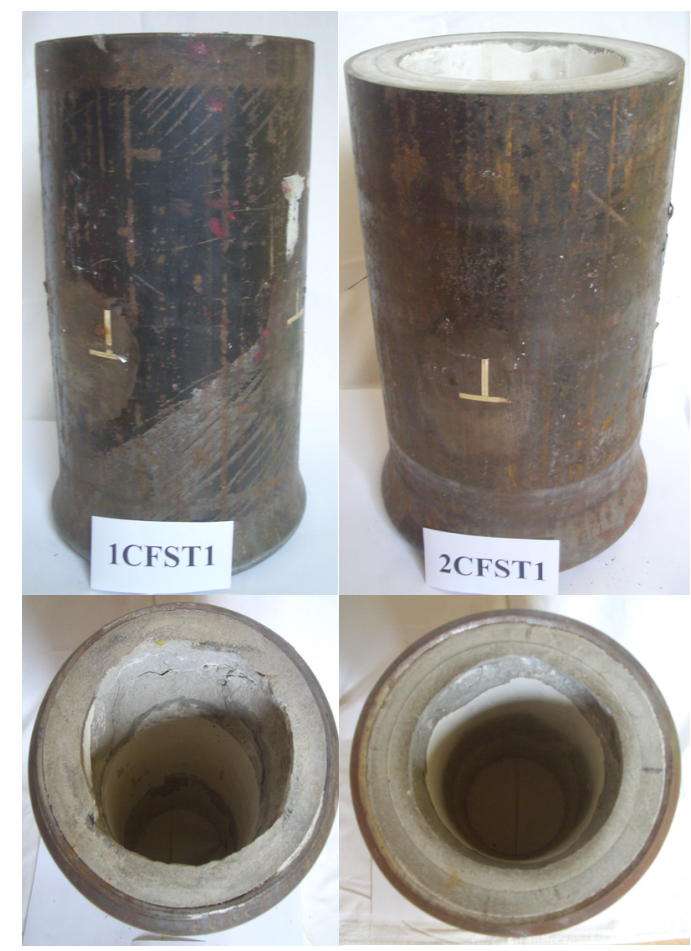

Fig 13. Single- and double-layered H-CFST tested specimens

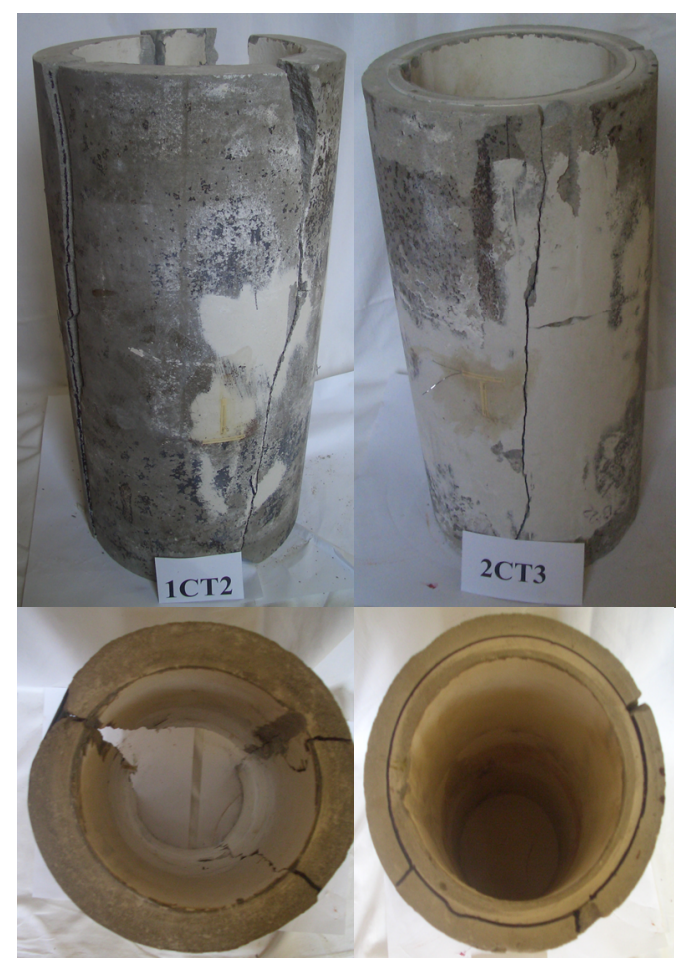

Fig 14. Single- and double-layered H-CT tested specimens

Specimens ST, H-CT and H-CFST after testing are presented in Figs 12-14 respectively. All test results in [9].

\section{Conclusions}

Hollow concrete-filled steel elements of annular cross-section have an advantages in respect of the solid ones. Multi-layered elements due to mechanical and technological reasons achieve better physical and mechanical properties, thus the load-bearing capacity of these members is increased.

Mechanical behaviour of the concrete mix during spinning is quite a complicated process and depends on many factors. Thus recommendations for proportioning the concrete mix components, calculation of the time needed and radial pressure required for each step of spinning are necessary before manufacturing can start.

Results of experiments carried out in this investigation confirm the spinning theory [22]. More excess residual water is pressed out from double-layered elements, thus $(W / C)_{\text {res }}$ decreases, and this leads to a lower porosity and greater density of concrete; therefore the compression strength of H-CFST and H-CT members is increased.

Further investigations of $\mathrm{H}-\mathrm{CFST}$ and $\mathrm{H}-\mathrm{ST}$ are needed, especially with coarse aggregates, for members with more than 2 layers, and for slender members.

\section{References}

1. SEWEL, J. S. Columns for buildings. Engineering News, 1902, 48(17), p. 36-39.

2. ZHONG, S.; and ZHANG S. M. A new method from China to determine load-carrying capacity for CFST members. In Proc of the Engineering Foundation Conference: Composite Construction in Steel and Concrete II, Potosi, Missouri, USA, 14-19 June 1998. Ed by D. Darwin and D. Dale Buckner, p. 499-511.

3. ZHONG, S. Application and research achievement of concrete filled steel tubular (CFST) structures in China. In Proc of the 8th International Conference on SteelConcrete Composite and Hybrid Structures, Harbin, China, 12-14 Aug 2006, p. 24-29.

4. ZHONG, S.; and ZHANG, S. Application and development of concrete-filled steel tubes (CFST) in high rise buildings. Advances in Structural Engineering, 1999, 2(2), p. 149-159.

5. ZHONG, S.; CHENG, H. T.; and ZHANG S. The continuity of behaviours for circular, square and octagonal forms for concrete filled steel tube (CFST) members under axial compression. Steel Structures, 2002, 2, p. 81-85.

6. ZHONG, S.; CHENG, H. T.; and ZHANG, S. Behaviours and strength of concentrically loaded short concrete-filled steel HS columns with different cross-section geometries. Advances in Structural Engineering, 2004, 7(2), p. 113127.

7. XINBO, M.; ZHANG, S.; and GOODE, C. D. Comparison of design methods for circular concrete-filled steel tube columns in different codes. In Proc of the 8th International Conference on Steel-Cozncrete Composite and hybrid Structures, Harbin, China, 12-14 Aug 2006, p. 3037.

8. HAN, L. H.; and YANG, Y. F. Analysis of thin-walled steel RHS columns filled with concrete under long-term sustained loads. Thin-walled Structures, 2003, 41, p. 849870 . 
9. HAN, L. H.; and YAO, G. H. Influence of concrete compaction on the strength of concrete-filled steel RHS columns. Journal of Structural Steel Research, 2003, 59(6), p. 751-767.

10. HAN, L. H; and YAO, G. Behaviour of concrete-filled hollow structural steel (HSS) columns with pre-load on the steel tubes. Journal of Constructural Steel Research 2003, 59, p. 1455-1475.

11. MURSI, M.; UY, B., and BRADFORD, M. A. Interaction buckling of concrete filled columns using high strength steel. In Proc of the ASSCCA'03 international conference advances in structures (ASCCS-7), Sydney, Australia, 2225 June, 2003, p. 863-869.

12. TAO, Z.; and HAN, L. H. Tests and mechanics model for concrete-filled double skin steel tubular stub columns. In Proc of the ASSCCA'03 International Conference Advances in Structures (ASCCS-7), Sydney, Australia, 22-25 June, 2003, p. 899-905.

13. HAN, L. H.; ZHONG, T.; and WEI, L. Effects of sustained load on concrete-filled hollow structural steel columns. Journal of Structural Engineering ASCE, Sept, 2004, p. 1392-1404.

14. KVEDARAS, A. K. Theory and practice of concrete-filled steel tubes (Betonšerdžiu vamzdinių plieno konstrukciju teorija ir praktika). Habilitation thesis, Vilnius Gediminas Technical University, Vilnius, 1999. 82 p. (in Lithuanian).

15. KURANOVAS, A.; and KVEDARAS, A. K. Investigation of shear transfer between components of hollow concrete-filled steel elements. In Proc of the XII LSCE 2006, 1 Dec 2006. Ed by J. B. Obrębski, p. 60-67.
16. JOHANSSON, M.; and GYLILTOFT, K. Mechanical behaviour of circular steel-concrete composite stub columns. Journal of Structural Engineering, 2002, 128(8), Aug, p. 1073-1081.

17. ZHONG, S.; and ZHANG, S. A new method from China to determine load-carrying capacity for CFST members. In Proc of the engineering foundation conference: Composite construction in steel and concrete II. 1998, p. 499511.

18. BRAUNS, J.; and ROCENS, K. The effect of material strength on the behaviour of concrete-filled steel elements. Journal of Civil Engineering and Management, 2004, 10(3), p. 177-182.

19. ŠARAŠKINAS, V.; and KVEDARAS, A. K. Kabamosios trilankstès betonšerdžių tuščiaviduriu vamzdiniu plieno strypų konstrukcijos įlinkių skaičiavimas. Journal of Civil Engineering and Management, 2001, 7(2), p. 99-105.

20. BLAŽEVIČIUS, Ž.; and KVEDARAS, A. K. Experimental investigation into fire resistance of HC-FST columns under axial compression. Journal of Civil Engineering and Management, 2007, 13(1), p. 1-10.

21. KURANOVAS, A.; and KVEDARAS, A. K. Behaviour of hollow concrete-filled steel tubular composite elements. Journal of Civil Engineering and Management, 2007, 13(2), p. 131-141.

22. ACHVERDOV, I. N. Oppressive reinforced concrete spinned tubes (Железобетонные напорные центрифугированные трубы). Moscow: Stroyizdat, 1967. 164 p. (in Russian).

\section{TUŠČIAVIDURIŲ BETONŠERDŽIŲ PLIENINIŲ VAMZDINIŲ STRYPŲ GAMYBOS TECHNOLOGIJA IR PRANAŠUMAI}

\section{A. Kuranovas, A. K. Kvedaras}

Santrauka

Tuščiaviduriai betonšerdžiai plieniniai vamzdžiai (TBPV) yra vienas iš kompozitinių konstrukcijų tipų. Tokie elementai dažniausiai gaminami centrifugavimo būdu, kai betono skiedinys ịpilamas i plieninị vamzdị ir tankinamas centrifuguojant, dèl to betonas igyja geresnių fizinių ir mechaninių savybių lyginant su plačiau naudojamais tankinimo metodais. Šios savybès yra tankis, tamprumo modulis, Puasono koeficientas, gniuždomasis stipris, deformacijos, skiedinio užpildo pasiskirstymo vienodumas per gaminio storị. Šiame straipsnyje yra pateikiami centrifugavimo proceso ypatumai, betono skiedinio komponentų kiekio, proporcijų nustatymo, jų savybių, centrifugavimo laiko parinkimo, bandymo eigos ir bandymo metodų rekomendacijos.

Reikšminiai žodžiai: kompozitinès konstrukcijos, tuščiaviduriai betonšerdžiai plieniniai vamzdžiai, daugiasluoksnès šerdys, centrifugavimas, gamyba, technologija.

Artiomas KURANOVAS. PhD student at Dept of Steel and Timber Structures. Vilnius Gediminas Technical University, Sauletekio al. 11, LT-10223 Vilnius, Lithuania.

A graduate of Civil Engineering at Vilnius Gediminas Technical University (2002). MSc of civil engineering (2004) at Vilnius Gediminas Technical University. Research interests: structural mechanics, composite elements and behaviour of their components, engineering software for structural elements design. Member of association of steel-concrete composite structures (ASCCS) and council on tall building and urban habitat (CTBUH).

Audronis Kazimieras KVEDARAS. Prof Dr Habil at the Dept of Steel and Timber Structures and Director of the Innovatory Scientific Institute of Special Structures "Kompozitas" of Vilnius Gediminas Technical University, Sauletekio al. 11, LT-10223 Vilnius, Lithuania.

Research interests: steel, composite steel-concrete and timber structures. Member of international association for brigde and structural engineering (IABSE) and association of steel-concrete composite structures (ASCCS), NATO invited expert (1996, 2000). 